\title{
The Precarities of International Travel
}

Tiffany M. Gill (D)

Wilburn Taylor and his wife wanted to go on vacation. In the summer of 1955, they looked ahead to the impending winter weather and longed for the blue skies and warm welcome that were promised in the travel brochures that drew by then over 1.5 million Americans annually to the Caribbean. ${ }^{1}$ Economic prosperity, advances in transportation, and an emphasis on consumption as a marker of middle class identity had precipitated a golden age of leisure and vacationing for Americans after World War II. ${ }^{2}$ The Taylors saved their money, asked for time off from work, and after doing some research, settled on a perspective itinerary with stops across the West Indies. The promise of sun and sand excited them, but important uncertainties remained. In a terse but revealing inquiry sent to the Pittsburgh Courier, a leading Black newspaper with a national weekly circulation of 300,000 copies, Taylor stated that he and his wife "are colored people and ... would like to find out about the color question and hotel accommodations in these countries ...". He was so desperate for advice that he was willing to pay for it. ${ }^{3}$

The Taylors were not alone. Letters from would-be vacationers with concerns about discriminatory practices flooded the pages of the Courier. Given the longstanding Jim Crow laws and corrosive racial etiquette in the United States, African Americans could never assume the right to access or enjoy many public accommodations at home. But knowledge and support gained through formal and informal networks allowed them to at least prepare for what they might encounter when moving within their own nation's borders. When it came to travel outside of the United States, by contrast, uncertainties abounded. Too few had gone, and different cultural norms and languages made the terrain even more difficult to decipher. Yet with the unknown came the elusive possibility that by traveling abroad one could, albeit temporarily, escape the burden of American anti-blackness. For African Americans, the international color line was a tightrope, where they had to balance the unknown perils of international leisure travel with the potential pleasures of a vacation free from racial discrimination.

Black print media served as a key resource for vacation seekers hoping to navigate the precarities of the international color line. Not only did travelers solicit advice, but an eclectic and unexpected group of travel boosters and entrepreneurs wrote articles, manned travel columns, and created guides to discuss and debate the complexities of being a postwar Black consumer, cosmopolitan, and vacationer. Most of the major Black periodicals in the postwar period, from the Courier to the Chicago Defender to the Baltimore Afro-American, carried an annual

I would like to thank LaShawn Harris, Shannon King, and the participants of the "Encounters: Travel and Tourism in Historical Perspective" symposium at Seton Hall University for their comments and insights on earlier drafts of this essay.

${ }^{1}$ For more on the increase in numbers of American tourists going to the Caribbean in the 1950s, see George Gmelch, Behind the Smile: The Working Lives of Caribbean Tourism (Bloomington, IN, 2003), 8.

${ }^{2}$ Although Lizbeth Cohen does not address travel extensively, her notion of postwar "consumer citizens" is important to understanding the rise in travel. See Lizbeth Cohen, A Consumers' Republic: The Politics of Mass Consumption in Postwar America (New York, 2003). Sarah Sessions Rugh frames this period as the "golden age of vacationing" in her book Are We There Yet? The Golden Age of American Family Vacations (Lawrence, KS, 2008), but looks primarily at domestic travel.

"Courier Guide for Travelers," Pittsburgh Courier, July 11, 1955, 5.

(C) The Author(s), 2021. Published by Cambridge University Press. This is an Open Access article, distributed under the terms of the Creative Commons Attribution licence (http://creativecommons.org/licenses/by/4.0/), which permits unrestricted re-use, distribution, and reproduction in any medium, provided the original work is properly cited. 
vacation section and a weekly travel advice column. Popular magazines like Ebony featured glossy multipage pictorials, while Jet printed a weekly "Travelogue" section on its society page focused on international destinations. Guidebooks like the Green Book and Travelguide provided lists of hotels, private guesthouses, eateries, and pharmacies, as well as beauty and barbershops that would welcome Black patronage throughout the globe (Figure 1). However, most of the scholarly and popular treatments of these manuals focus on how they address the perils of domestic car travel to the exclusion of the publications' extensive coverage and conversations about Black international leisure travel. ${ }^{4}$

The popularity and ubiquity of stories about international tourism in the Black press framed the ways many African Americans viewed the world and their place in it. However, leisure and consumption practices are not often considered in scholarly discussions of African Americans' expanding global sensibilities in the post-World War II era. ${ }^{5}$ Taking international leisure travel seriously complicates the contours of Black global alliances and highlights the intricacies of the international color line. Never were these complexities more pronounced than when African Americans traveled to the Caribbean, a region where they had a shared African-descended heritage with many of the local people, but also a place where their connection to American empire set them apart from their diasporic kin.

The writer and activist Langston Hughes became an unlikely booster for African American leisure travel. In 1948 he took to the pages of Ebony magazine to tout what he considered the "perfect vacation spot"-Jamaica. Ebony, created by John H. Johnson just three years earlier, showcased postwar African Americans as consumers and unapologetic leisure seekers. However, the magazine struggled to court advertising dollars from the travel industry in the early years, so Johnson paid photographers and writers like Hughes to create copy that blurred the line between journalism and advertising. ${ }^{6}$ Hughes, by then a venerated man-of-letters and a world traveler who had written extensively about the Caribbean, used his poetic virtuosity to describe Jamaica as a place that was easy to reach, inexpensive, flowing with rum, adorned with sun-kissed beaches, and, most importantly, "prejudice-free." $\mathrm{He}$ even depicted the British colonial presence as a boon that gave the island an "English-African charm" that he thought African American travelers would find appealing. This simplicity was a major departure for Hughes who had already spent much of his life critiquing colonialism in the Caribbean and highlighting the global reach of Jim Crow. In fact, just three years earlier in the Chicago Defender, Hughes lamented that death was the only thing that could erase segregation. Now on the pages of Ebony, Hughes proposed that a Jamaican vacation could provide a welcome escape from the color line this side of eternity. ${ }^{7}$

For Hughes, Jamaica was a racial utopia. The only mention of discrimination was as a relic of the past and due to U.S. imperial intervention. He noted that that the Myrtle Bank Hotel,

\footnotetext{
${ }^{4}$ Recent digitization of the Green Book by the New York Public Library has led to an abundance of interest about the guides in media and popular culture. Two recent works, Gretchen Sorin, Driving While Black: African American Travel and the Road to Civil Rights (New York, 2020) and Candacy Taylor, Overground Railroad: The Green Book and the Roots of Black Travel in America (New York, 2020), counter narratives about automobility and road trips as an exercise of freedom. With the exception of Gretchen Sorin, most examinations of the Green Book ignore its extensive coverage of international destinations.

${ }^{5}$ Notable exceptions are Frank Andre Guridy, Forging Diaspora: Afro-Cubans and African Americans in a World of Empire and Jim Crow (Chapel Hill, NC, 2010); and Kim Gallon, "Black Women's Internationalism and the Chicago Defender During the Golden Age of Haitian Tourism," in To Turn the Whole World Over: Black Women and Internationalism, 1st ed., eds. Keisha Blain and Tiffany Gill (Urbana, IL, 2019), 55-73.

${ }^{6}$ Adam Green, Selling the Race: Culture, Community, and Black Chicago, 1940-1955 (Chicago, 2009), $153-5$.

${ }^{7}$ For some examples of Hughes's critiques of the Caribbean color line and the need for African Americans to join in the global fight against colonialism, racism, and classism, see Langston Hughes, The Collected Works of Langston Hughes, vol. 14: Autobiography: I Wonder as I Wander (Columbia, MO, 2003); Langston Hughes, The Big Sea: An Autobiography (New York, 1940); and Langston Hughes, "The Purple Heart," in Langston Hughes and the Chicago Defender: Essays on Race, Politics, and Culture, 1942-62, ed. Christopher C. De Santis (Champaign, IL, 1995), 153-4.
} 


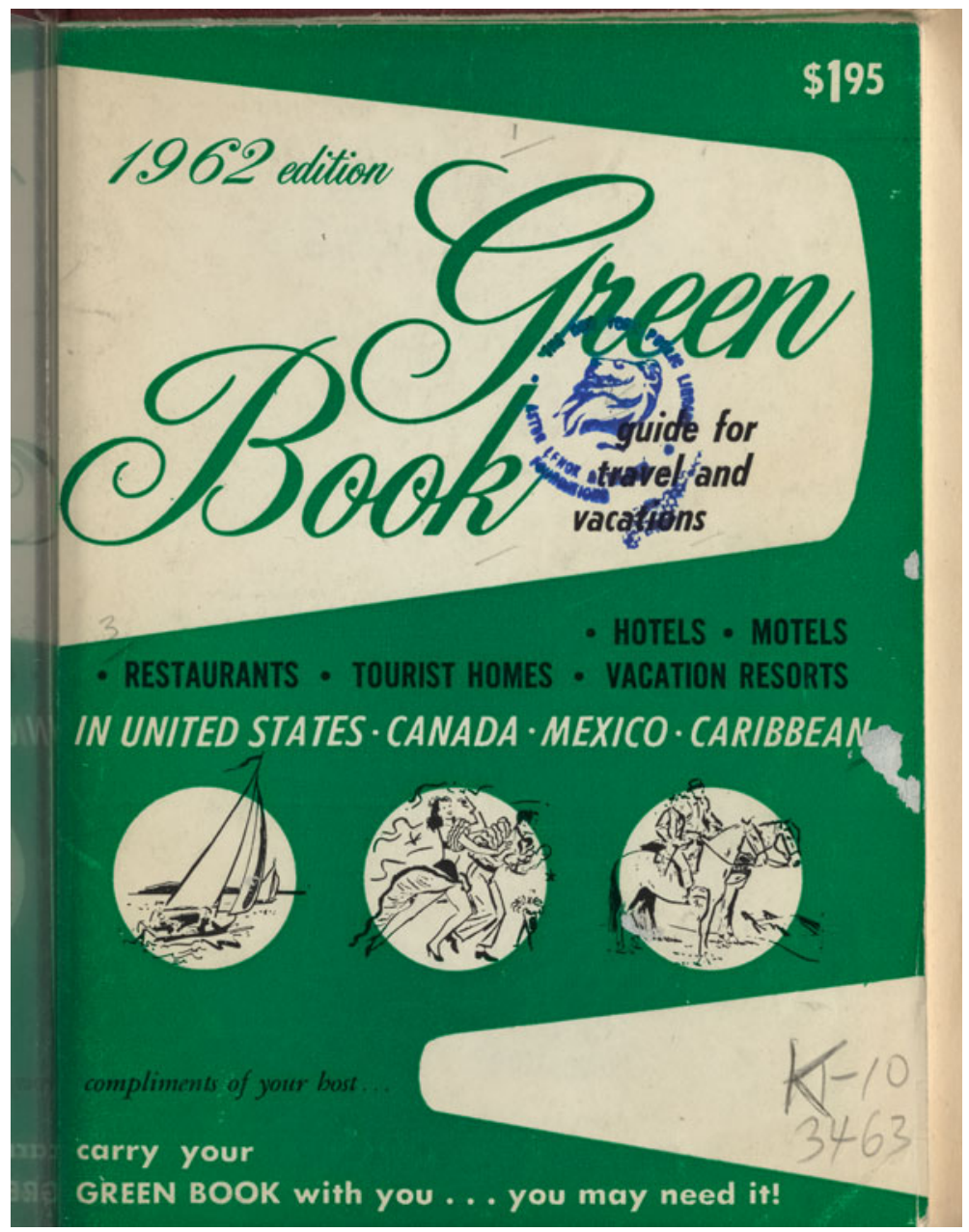

Figure 1. "Green Book: 1962." New York Public Library Digital Collections. Public domain. http://digitalcollections.nypl. org/items/786175a0-942e-0132-97b0-58d385a7bbd0

once owned by the United Fruit Company_ “an American firm, God help us!" - did not welcome Black guests, forcing them into attic rooms, if allowing them to stay at all. "But now," Hughes rejoiced, "the hotel belongs to the Issa family (Syrians) and the color bar is broken." With the sale of the hotel to non-Americans, Hughes wanted his readers to believe that the scourge of racial inequality was no longer an issue and instead invited them to bask in the glorious blackness of the island. "Everywhere along the highway and in the city street," Hughes enlightened, "everybody was colored." By end of the six-page advertorial, Hughes left no uncertainty about how he felt about the island nation and the possibilities it held for Ebony's readers seeking to escape the perils of the color line. In a couplet of sentences, he came to his overall assessment: "Jamaica is a calm and beneficent island with few if any plagues. Certainly, it is not plagued by Jim Crow, which is a very great blessing for colored vacationists." 10

\footnotetext{
${ }^{8}$ Langston Hughes, "Jamaica: Easy to Reach Paradise Offers Perfect Prejudice-Free Vacation Spot," Ebony, Nov. $1948,49$.

${ }^{9}$ Hughes, "Jamaica," 48.

${ }^{10}$ Hughes, "Jamaica," 49.
} 
Hughes depiction of a nation full of empowered Black people and absent of racial hierarchies did not intersect at all with the way white travel companies portrayed blackness on the island. Instead, they employed images of Black servitude to lure white visitors to the Caribbean. For example, a brochure from the early 1950s from the Silver Sands hotel featured white tourists lounging at a beach while a Black man clad in a butler uniform bent his back to serve them drinks. ${ }^{11}$ The image of the obsequious Black servant ran counter to the cosmopolitan African American consumer Ebony magazine sought to convey on its pages. In other words, in Hughes's attempt to undo the racial fantasies of the white-driven tourist industry, he perpetuated a parallel world of make believe that ignored the lived experiences of Black Jamaicans and the international dimensions of the color line.

One month after Hughes's essay appeared, Ebony published a letter to the editor from a selfidentified native Jamaican, currently living in New York City, W. A. Domingo. That name would have been immediately recognizable not only to Hughes but to many of Ebony's readers. Born Wilfred Aldophus Domingo in 1889, he immigrated to Harlem in 1910 and became entrenched in the New Negro movement as an advocate for racial and economic justice for Black people across the diaspora. A journalist by trade, Domingo once edited the Negro World, the mouthpiece of his fellow countryman Marcus Garvey's Universal Negro Improvement Association, and contributed to A. Philip Randolph's Messenger before establishing his own short-lived weekly, The Emancipator. An avowed socialist, Domingo often found himself at odds with Garvey's narrow focus on race to the exclusion of the class struggle. Instead, he found an ideological home with the more militant activist-intellectuals of the African Blood Brotherhood, a radical organization that merged the battles against racism, colonialism, and capitalism, and advocated armed self-defense. Domingo moved back to his homeland to work for Jamaican independence in the early 1940s before returning to the United States a few years before penning his letter to Ebony. ${ }^{12}$

Domingo agreed with Hughes that there was "no more beautiful spot on earth" than Jamaica, but he took great objection to his representation of the island:

It is when Mr. Hughes attempts to discuss the existence or non-existence of color prejudice that I find myself in total disagreement with him. There is color prejudice in Jamaica. To the average American of color, the color line in Jamaica is not obvious, to use Mr. Hughes' word. But that does not preclude the existence of a color line. ${ }^{13}$

He refuted Hughes's observations with his own first-hand knowledge. For example, while Hughes marveled that "tan-skinned youngsters" played freely at the swimming pool of a hotel, Domingo described an incident just three years earlier when the Black editor of one of Jamaica's leading publications was denied entry into that same pool. Domingo wanted Ebony's Black American readers to realize that their favorable treatment in Jamaica was bought by their U.S. dollars and that native Jamaicans were constrained by the very color line that they wanted to escape.

Domingo also wanted to make it clear to Black Americans that the discrimination that prevented native-born Jamaicans from partaking in many of the island's leisure spaces might also hinder their enjoyment. He argued that Hughes's lighter complexion impacted his experience on the island and that the "average American Negro" with darker skin should not expect to be treated much better than they would be in United States. He refuted Hughes's perception of

\footnotetext{
${ }^{11}$ See Jamaican Hotel History, "Silver Sands Beach Club, Montego Bay Jamaica, mid-1950s," accessed October 7 , 2020, http://jamaicahotelhistory.com/brochures/Silver-Sands-mid-1950s.htm.

${ }^{12}$ For more on W. A. Domingo, see Minkah Makalani, In the Cause of Freedom: Radical Black Internationalism from Harlem to London, 1917-1939 (Chapel Hill, NC, 2014); and Lara Putnam, Radical Moves: Caribbean Migrants and the Politics of Race in the Jazz Age (Chapel Hill, NC, 2013).

${ }^{13}$ W. A. Domingo, letter to the editor, “The Truth about Jamaica," Ebony, December 1949, 4.
} 
Morgan's Cove, a popular nightclub Hughes lauded for being an integrated space. According to Domingo, four Black Americans had recently attempted to enter the club for a night of drinking and dancing. One of the travelers, a woman, who Domingo pointed out was the darkest in the group, was denied entry. Domingo explained that African American visitors with money and light skin could move about the island with some ease, "but the dark-skinned American Negro (especially a woman) is likely to run into embarrassing situations." ${ }^{14}$ The color line in Jamaica may not have operated according to American Jim Crow's strict black/white binary that cared little about complexion or wealth, but in no uncertain terms, Domingo warned that color prejudice was alive and well on the island.

Blinded by his own skin color privilege or perhaps pressured by Ebony to entice tourists, Hughes failed to prepare travelers, especially darker skinned ones, for the peculiarities of Jamaica's color line. No wonder Wilburn Taylor had so many questions about how he and his wife would be treated in the Caribbean when he wrote to the Pittsburgh Courier a few years later. ${ }^{15}$ The person who fielded Taylor's question at the Courier's travel advice page was the musician-turned-travel-entrepreneur Billy Butler, founder of King Travel Organization, one of the first fully accredited Black-owned travel companies in the United States. ${ }^{16}$ Unlike Hughes, Butler conceded that in the locations they wished to visit "there is some prejudice to be encountered but we can guarantee good accommodations in each of the countries you visit." In other words, he did not ignore or conceal the realities of racial prejudice in the Caribbean. Instead, he acknowledged the problem and positioned his travel business as the solution.

Navigating the international color line precipitated a Black travel agency boom in the 1950s and 1960s. Billy Butler was joined by entrepreneurs like Freddye Henderson in Atlanta, who not only helped middle-class African American vacationers find dignified leisure, but through her close relationship with Martin Luther and Coretta Scott King also played a role in dismantling Jim Crow at home by fighting for the desegregation of Atlanta's airport. ${ }^{17}$ Butler not only gave travel advice in the Courier, but also penned a six-part series called "Travel versus Discrimination" that ran in the spring of 1954 and called for direct action to dismantle segregation years before the sit-in movement of the 1960s. ${ }^{18}$ Billy Butler and the cadre of Black travel entrepreneurs that emerged after World War II were not just interested in helping middle-class African Americans successfully avoid humiliations while vacationing abroad. They also advocated for a wider vision of a Black consumer citizenship, which compelled them to make claims for African Americans' freedom at home.

The postwar era opened up new opportunities for travel to the Caribbean, but often left African Americans with the same old questions about whether they would be able to enjoy themselves. The color line did not magically disappear when African Americans left the shores of the United States; however, its boundaries were often so nebulous that it was hard to know what to expect. As postwar tourists, travel boosters, and entrepreneurs filled the pages of the Black press with their hopes, fears, and expectations, they opened up a rich conversation about blackness, consumption, and the right to dignified leisure, even for those who never

\footnotetext{
${ }^{14}$ Domingo, "The Truth about Jamaica," 4.

${ }^{15}$ For more on the transformations in the "Negro consumer market" in the 1950s, see Green, Selling the Race; Brenna Wynn Greer, Represented: The Black Imagemakers Who Reimagined African American Citizenship (Philadelphia, 2019); and Robert E. Weems, Desegregating the Dollar: African American Consumerism in the Twentieth Century (New York, 1998).

16“Negro Tourist Market Offers Big Potential," undated clipping, folder 1, box 1, William H. Butler Papers, Schomburg Center for Research in Black Culture, New York Public Library, NY.

${ }^{17}$ See the discussion of Freddye Henderson's involvement in Coke v. Atlanta in Anke Ortlepp, Jim Crow Terminals: The Desegregation of American Airports (Athens, GA, 2017), 69-75.

${ }^{18}$ Billy Butler, “Travel versus Discrimination," Pittsburgh Courier, Apr. 3, Apr. 10, Apr. 17, Apr. 24, May 1, May $8,1954$.
} 
left the United States. Scholarly treatments of post-World War II Black internationalism are incomplete without recognizing how the desire to find a temporary respite from segregation and to be recognized as a viable consumer market transformed the long struggle for Black freedom.

Tiffany M. Gill is an Associate Professor of History at Rutgers University, New Brunswick, NJ. The author of Beauty Shop Politics: African American Women's Activism in the Beauty Industry and co-editor with Keisha N. Blain of To Turn this Whole World Over: Black Women and Internationalism, she is currently at work on a book on the promise and peril of African American international leisure travel since World War I. You can find her on social media @SableVictorian. 